\title{
Impact of Economic Reforms, FDI and Imports on GDP: Trends and Regression Analysis
}

\author{
Aamir Jamal ${ }^{1}$, Waseem Hassan Khan ${ }^{2}$ and Binish Qadri ${ }^{3}$ \\ Research Scholar, Department of Economics, Central University of Kashmir, Jammu and Kashmir, India \\ E-Mail: aamirjamal06@gmail.com, waseemkhan160@gmail.com, qadribinish@gmail.com
}

\begin{abstract}
The objective of the present study was to examine the impact of new economic reforms of 1991 on Indian economy in general and GDP growth rate in particular. From the trend analysis of GDP and its major determinants, it was found that all variables performed really well in the post reform period in contrast to the pre reform period. The regression analysis confirmed that the GDP growth of India is significantly affected by imports and surprisingly FDI inflows were found to be insignificant. A dummy variable which was incorporated as a proxy variable for economic reforms of $\mathbf{1 9 9 1}$ was found to be positive and significant which asserted that the economic reforms had made a positive impact on GDP growth of India. To enhance the GDP growth, the imports should be further enhanced; the composition of imports should be directed towards capital goods rather than consumer goods imports. Distribution of FDI should be organized in a systematic and coherent manner and should not be just directed towards white goods industries which cater the needs of rich sections of society. Some portion of FDI inflows should be directed towards smaller projects, (unregistered manufacturing) which in country like India augments employment levels thereby increasing the production and productivity. Finally, in order to boost the GDP growth in India it is argued that the important constituents of GDP should be further promoted through liberal policies in a systematic manner.
\end{abstract}

Keywords: Reforms, GDP, FDI, Imports, Trends, Regression

\section{INTRODUCTION}

The restrictive measures which were adapted by the government of India for many decades after independence did nothing as far as reducing income inequalities, improving health facilities, and promoting education are concerned (Sen and Dreze, 1995). It was also found that Indian economy stagnated around 3.5 percent per annum for almost three decades after independence (Hindu growth rate). One can say that the objectives which were set before the implementation of the highly regulated/planned economy for India were not achieved the way they should have been. The BOP crisis in early 1990's which came into existence due to the persistent macroeconomic mismanagement of the economy (Virmani, 2001) prevailed in entire 1980's, resulted in high fiscal deficit, current account deficit, inflation etc. With the success of the market-oriented reforms in lowering the poverty, inequalities of income and wealth and unemployment in East Asian economies (Quibria, 2002), the attention of the Indian policy makers got shifted towards more liberal measures based on market forces. In addition to that the change of attitude towards market-oriented reforms of Indian policy makers (Rodrik, 2002) got a huge impetus indirectly when IMF directed India to follow more liberal measures. With the inception of new economic reforms of 1991 based on concepts of Liberalization, Privatization and Globalization, a package of market-oriented reforms was introduced in diversified sectors like trade, industry, foreign investment etc. Since, there has been a change in Indian economy from a heavily regulated economy prior to 1990's towards a more liberal economy based on market forces, (Ahluwalia, 2002) it becomes necessary to study the impact of new economic reforms on Indian economy in general and few sectors in particular. New economic reforms of 1991 were also intended to take India out of the clutches of Hindu growth rate of 3.5 percent per annum. Although India did witness the higher growth rate in 1980's but that was unsustainable (Panagariya, 2004). So, it becomes logical to make a comparative study of the performance of the Indian economy in the pre and post reform period. Therefore, the study has selected few crucial macro-economic variables like Imports, FDI inflow and GDP to empirically test their performance in the pre and post reform period.

\section{REVIEW OF LITERATURE}

Borensztein et al. (1998) in his paper tried to analyze the impact of FDI inflows from various industrialized nations to almost 69 developing countries. It was revealed by the study that FDI inflows promote economic growth. But higher productivity of FDI inflows is only possible when in the host countries there are sufficient absorptive capacities of the modern technologies.

Ahluwalia (2002) has written that India was a latecomer to market-oriented reforms. It was inevitable that the interventionist regimes had a little role to play in developing nations as market-oriented reforms proved to be a success in East Asian economies which achieved high growth rates along with simultaneous reduction in the poverty It was found that annual average GDP growth rate from 1992-1993 to 2001-2002 was around 6.0 percent which during that decade put India among the fastest growing economies around the globe.

Din (2004) in his study tried to analyze the relevance of import and export led growth hypothesis for South Asian region taking a sample of five largest economies of South Asia. He found that there is bidirectional causality between 
exports and growth (output) in countries namely India, SriLanka and Bangladesh in short period of time. Besides this it was empirically tested that there existed long run relationship between exports, imports and output in Pakistan and Bangladesh but no such relationship was found in SriLanka and Nepal which was against the earlier findings of various research studies in these regions which revealed that there existed a long run relationship between exports imports and output in all the five countries.

Sarkar and Bhattacharyya (2005) in their paper tried to empirically test whether trade liberalization or openness have a positive impact on real GDP or GDP per capita for Korean and Indian economy using annual time series data of both of the countries from 1956-1999 for Indian economy and from 1956-2001 for Korean economy. Study used three kinds of proxy variables for measuring trade openness or liberalization i.e. Exports/GDP (X/GDP), Imports/GDP (M/GDP).Exports+ Imports/GDP(X+M/GDP).ARDL technique was used by the study. Finally, the results of the study revealed that there is no meaningful relationship between real GDP and trade liberalization.

Dasgupta (2009) has assessed the impact of exports, imports and FDI inflows on FDI outflows from India for a time period ranging from 1970-2005, using Vector Error Correction model (VECM). Data regarding the concerned variables was collected from reputed international sources, world investment report and world development indicators. The study revealed that the imports had made a positive and significant impact on FDI outflows. In fact, it was found that there was unidirectional causality between the imports, exports and FDI outflows. In contrast to FDI inflow and outflow no such causality was found between the variables. Finally, it was recommended by the study that in order to improve the capability of investing in rest of the world, our prime focus should be to strengthen domestic trade.

Rai (2015) has tried to analyze the dependence of GDP growth on exports and imports after economic reforms of 1991. The various measures were taken in and after 1991 to dismantle various stumbling blocks to free trade. It was observed that in the determination of GDP growth rate both of the above said variables i.e. exports and imports have affected it significantly in the post reform period. Furthermore, from the regression analysis it was revealed that the growth rate was more affected by imports than exports as the composition of imports which mainly consisted of capital goods and intermediate goods which are used for further production. Granger causality test also revealed that the exports were being affected by imports.

\section{RESEARCH METHODOLOGY AND DATA SOURCES}

The study is purely based on secondary sources of data extracted from world developmental indicators (World Bank). To analyse the performance of various macroeconomic variables like GDP, imports and FDI inflows in the pre and post reform period the study has used annual time series from 1978 to 2013.The time period is further divided into two sub periods i.e. from 1978-1990 (pre-reform period) and 1991-2013 (post reform period).

To accomplish one of the objective of the study i.e. to study the trends in the pre and post reform period of GDP, imports, and FDI inflows the methodology used is very simple like Annual growth rate, Decadal growth rate, graphs etc.

Yearly growth rates are computed as under:

$G_{t}=\frac{Y_{t}-Y_{t-1}}{Y_{t-1}} \times 100$

$\mathrm{G}_{\mathrm{t}}=$ Growth rate for period $\mathrm{t}$.

$Y_{t}=$ Value of a variable in period $t$.

$\mathrm{Y}_{\mathrm{t}-1}=$ Value of the variable in period $\mathrm{t}-1$.

For studying the relationship between Gross Domestic Product growth rate (GDPgr) (growth rate) and its determinants i.e. Foreign Direct Investment Inflows growth rate(FDIgr) and Import growth rate (Impgr) simple regression analysis has been used. In addition to that in order to analyse the impact of economic reforms of 1991 on GDP growth rate (GDPgr) a dummy variable (Dum) has been used as a proxy variable for economic reforms of 1991 and is incorporated into the Regression analysis.

Basic equation of the Regression analysis (Model equation) $($ GDPgr $)=\beta 0+\beta 1($ Impgr $)+\beta 2($ FDIgr $)+\beta 3$ Dum + et

Where GDPgr is the growth rate of Gross Domestic Product, Impgr is the growth rate of imports and FDIgr is the growth rate of Foreign Direct Investment Inflows. Dummy variable is a proxy variable used for economic reforms of 1991 . In addition to that $\beta 0$ is a constant term and $\beta 1$ is the coefficient of the respective explanatory variable (Impgr) that explains how the (Impgr) affects the GDP growth rate (GDPgr). Similarly $\beta 2$ is the coefficient of Foreign Direct Investment growth rate i.e. (FDIgr) which explains how FDI impacts the dependent variable and $\beta 3$ is the coefficient of Dummy variable.

\section{EMPIRICAL FINDINGS}

To study the trends in the pre and post reform period of all variables i.e. Gross domestic Product (GDP), Imports and FDI inflows, are presented in billion dollars at constant prices 2010 except FDI inflow which is presented in current dollars. In addition to that to make a comparative study in the trends of each of the variable the whole time period which is taken by study i.e. from 1980-2013 is further subdivided into two periods from (1980-1990) pre-reform period and (1991-2013) post reform period. In order to get proper insights in the trends of all the variables in both pre and post reform period various statistical techniques have been used in the study like annual growth rates, decadal growth rates. 
TABLE I TRENDS IN GDP IMPORTS AND FDI: 1980-2013

\begin{tabular}{|c|c|c|c|c|c|c|}
\hline \multicolumn{7}{|c|}{ (Values in US Billion \$) } \\
\hline Year & GDP & GDP ( $\%$ annual)* & Imports & Import (\%)* & FDI & FDI (\%)* \\
\hline 1980 & 271.69 & 6.73 & 18.64 & 14.35 & 0.07 & 62.98 \\
\hline 1981 & 288.01 & 6.00 & 20.511 & 10.02 & 0.09 & 16.11 \\
\hline 1982 & 298.02 & 3.47 & 21.21 & 3.45 & 0.07 & -21.58 \\
\hline 1983 & 319.74 & 7.28 & 25.88 & 21.98 & 0.00 & -92.17 \\
\hline 1984 & 331.96 & 3.82 & 22.17 & -14.33 & 0.01 & 241.1 \\
\hline 1985 & 349.40 & 5.25 & 25.25 & 13.87 & 0.10 & 451.40 \\
\hline 1986 & 366.09 & 4.77 & 29.56 & 17.08 & 0.11 & 10.97 \\
\hline 1987 & 380.61 & 3.96 & 29.07 & -1.66 & 0.21 & 80.34 \\
\hline 1988 & 417.25 & 9.62 & 31.74 & 9.19 & 0.091 & -57.02 \\
\hline 1989 & 442.07 & 5.94 & 32.40 & 2.08 & 0.25 & 176.2 \\
\hline 1990 & 466.53 & 5.53 & 33.49 & 3.36 & 0.23 & -6.11 \\
\hline 1991 & 471.46 & 1.05 & 33.50 & 0.01 & 0.07 & -68.93 \\
\hline 1992 & 497.31 & 5.48 & 40.58 & 21.12 & 0.27 & 276.01 \\
\hline 1993 & 520.93 & 4.75 & 48.40 & 19.26 & 0.550 & 99.039 \\
\hline 1994 & 555.62 & 6.65 & 59.33 & 22.60 & 0.973 & 76.83 \\
\hline 1995 & 597.71 & 7.57 & 76.02 & 28.12 & 2.14 & 120.24 \\
\hline 1996 & 642.83 & 7.54 & 74.17 & -2.43 & 2.42 & 13.17 \\
\hline 1997 & 668.87 & 4.04 & 83.96 & 13.20 & 3.57 & 47.45 \\
\hline 1998 & 710.23 & 6.18 & 101.46 & 20.84 & 2.63 & -26.35 \\
\hline 1999 & 773.06 & 8.84 & 108.56 & 6.99 & 2.168 & -17.68 \\
\hline 2000 & 802.75 & 3.84 & 113.54 & 4.58 & 3.58 & 65.27 \\
\hline 2001 & 841.47 & 4.82 & 116.88 & 2.94 & 5.128 & 43.07 \\
\hline 2002 & 873.48 & 3.80 & 130.91 & 11.99 & 5.20 & 1.57 \\
\hline 2003 & 942.14 & 7.86 & 149.08 & 13.88 & 3.68 & -29.31 \\
\hline 2004 & 1016.79 & 7.92 & 182.17 & 22.19 & 5.42 & 47.45 \\
\hline 2005 & 1111.20 & 9.28 & 241.54 & 32.58 & 7.26 & 33.89 \\
\hline 2006 & 1214.14 & 9.26 & 293.43 & 21.48 & 20.02 & 175.52 \\
\hline 2007 & 1333.14 & 9.80 & 323.34 & 10.19 & 25.22 & 25.95 \\
\hline 2008 & 1385.01 & 3.89 & 396.78 & 22.71 & 43.40 & 72.05 \\
\hline 2009 & 1502.46 & 8.47 & 388.30 & -2.13 & 35.58 & -18.02 \\
\hline 2010 & 1656.61 & 10.2 & 448.91 & 15.60 & 27.39 & -23.00 \\
\hline 2011 & 1766.58 & 6.63 & 543.45 & 21.05 & 36.49 & 33.22 \\
\hline 2012 & 1862.98 & 5.45 & 576.18 & 6.02 & 23.99 & -34.21 \\
\hline 2013 & 1981.95 & 6.38 & 529.24 & -8.14 & 28.15 & 17.32 \\
\hline
\end{tabular}

Source: World Bank national accounts data, and OECD National Accounts.

*Represents annual average growth rates

\section{A. Trends in GDP}

It is observed from Table I that GDP has been continuously increasing from 1980 onwards. With the introduction of new economic reforms of 1991, the GDP growth picked up the pace again from $4.75 \%$ in 1993 to $7.73 \%$ in 1999 . During this phase India was counted as one of the fastest growing economies of the world. Unfortunately, with the commencement of economic recession of 2008 there was a worldwide clampdown in the production. As India had USA a major trading partner its GDP growth rate got also reduced to $3.89 \%$ in 2008 .

From figure 1 although one can decipher that the fluctuations in the GDP growth rate can be witnessed throughout the both periods, but it is quite visible that the fluctuations in the growth rate or in other words the (variance in the growth rate) is significantly higher in the pre-reform period in comparison with the fluctuations of the GDP growth rates in post reform period. 


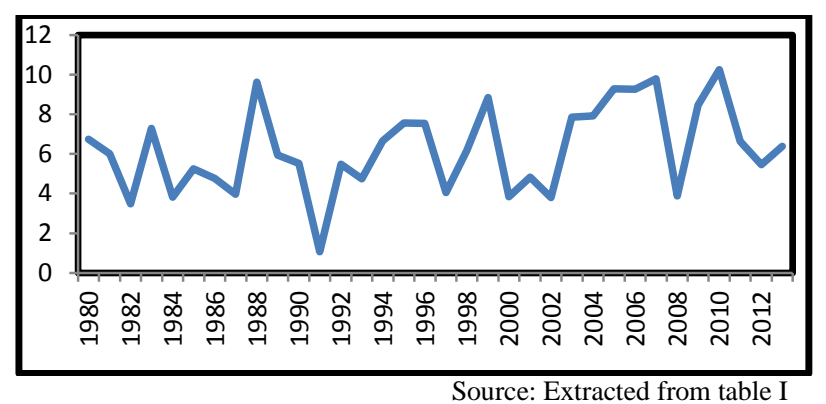

Fig. 1 Annual Growth Rate of GDP

TABle II AnNual Average Growth Rate OF GDP

\begin{tabular}{|l|c|c|}
\hline \multicolumn{1}{|c|}{ Periods } & GDP & Growth Rate \\
\hline $\begin{array}{l}\text { Pre Reform period } \\
(1980-1990)\end{array}$ & 357.40 & 5.70 \\
\hline $\begin{array}{l}\text { Post Reform period Phase I } \\
\text { (1991-2001) }\end{array}$ & 643.84 & 5.50 \\
\hline $\begin{array}{l}\text { Post Reform period Phase II } \\
\text { (2002-2012) }\end{array}$ & 1333.14 & 7.52 \\
\hline $\begin{array}{l}\text { Overall period } \\
(1980-2012)\end{array}$ & 778.13 & 6.20 \\
\hline
\end{tabular}

Source: Calculated on the basis of data given in Table I

In the pre-reform period the average annual growth rate for the entire period was found to be 5.70 per cent. Conventionally, one is made to think that due to the LPG measures introduced in 1991 the GDP growth rate should instantly increase a lot but it can be verified from the results in table II. In the first decade after the implementation of new economic reforms the average annual growth rate was found to be a bit lower in comparison to the pre-reform period as it was found to be 5.50 percent. These findings clearly reveal that there was no immediate effect of economic reforms on GDP growth rate. In contrast to these findings, it was found that in the second decade of the post reform period Indian economy performed very well in terms of annual growth rates as well annual average decadal growth rates. This era of high sustainable growth rates was disturbed with the introduction of the world economic recession of 2008, as a result of which it was found that in the year 2008 Indian economy just grew 3.8 percent. In addition to this there was a dip in the growth rates after 2010 as a result of which the average annual growth rate for the second phase or second decade of the post reform period was equal to 7.5 percent. This is better in comparison the average annual growth rate of first decade of the post reform period. It can be found that the overall impact of the economic reforms on the GDP growth rate was better in the post reform period as it can be calculated from table II that the average annual growth rate for the entire post reform period was roughly found to be $6.52 \%$ which is higher than the growth rate of pre reform as well of overall period which is approximately equal to 6.20 .

\section{B. Trends in Imports}

In 1980's it was believed that inward looking strategies for discoursing import could do nothing good for the country like India and to make Indian goods competitive in international markets, imports of foreign technology, capital equipment, spare parts etc. (Bhagwati \& Srinivasan, 2002) were considered to be very important for meeting the international standards of our exports. Thus, one can say that the actual liberalization in the country as far as imports are concerned started much earlier than new economic reforms of 1991 (Nayyar, 1987).

With the introduction of WTO in 1995 and as India one of its founding members and its commitment to adhere its strict laws against the quantitative restrictions, it was expected that India would continue with its liberal import policies and imports into the country in absolute terms would reach to those levels which had not been witnessed by the country until that period. In the second half of 1990's i.e. in the year 1996, first tariff line import policy was announced in which almost six thousand tariff lines were made free. Imports began to increase sharply in the second half of 1990's with an annual import growth rate of $21 \%$ recorded in the year 1998. To compliment all these efforts the EXIM polices of 2000-2001 and 2001-2002 removed quantitative restrictions from 700 and 715 items. In the prereform period the average annual imports in absolute terms was estimated to be of worth 26.36 billion dollars in comparison to the first decade of the post reform period where average annual value of imports was estimated to be equal almost 80 billion dollars. Table I and III clearly reveal that in the second decade after economic reforms of 1991, there were huge of imports goods and services made by the country as imports increased from 130 billion dollars in 2002 to 293 billion dollars in 2006.

TABle III ANNUAL AVERAgE GROWTH RATE OF IMPORTS

\begin{tabular}{|l|c|c|}
\hline \multicolumn{1}{|c|}{ Periods } & $\begin{array}{c}\text { Imports in } \\
\text { Billion Dollars }\end{array}$ & $\begin{array}{c}\text { Growth } \\
\text { Rate }\end{array}$ \\
\hline $\begin{array}{l}\text { Pre Reform period } \\
\text { (1980-1990) }\end{array}$ & 26.36 & 7.22 \\
\hline $\begin{array}{l}\text { Post Reform period Phase I } \\
\text { (1991-2001) }\end{array}$ & 77.85 & 12.47 \\
\hline $\begin{array}{l}\text { Post Reform period Phase II } \\
\text { (2002-2012) }\end{array}$ & 334 & 15.96 \\
\hline $\begin{array}{l}\text { Overall Post reform period } \\
\text { (1980-2012) }\end{array}$ & 146.07 & 11.88 \\
\hline Overall Period & 157.34 & 11.29 \\
\hline
\end{tabular}

When we make the comparative analysis of the decadal import growth rate in the pre and post reform period it can be clearly seen that the new economic reforms of 1991 made a significant impact on the imports into the country as in the pre-reform period, although the import liberalization had started in that era, the average annual decadal growth rate of imports was estimated to be about $7.22 \%$ and in the first decade of the post reform period it almost doubled to $12.50 \%$.The real thrust in the imports liberalization came in the second decade of the post reform period in which average annual growth rate of imports was estimated to be about $16 \%$ per annum. In addition to that there was a massive increase in the imports as it was found that the average annual imports in absolute value terms for this decade was estimated to be about 334 billion. So, without any ambiguity it can be concluded that economic reforms of 
1991, had made a significant impact on the import policy of the country.

\section{Trends in Net FDI Inflow}

FDI inflows into the country throughout the pre-reform period did not increase significantly, as the confidence of foreign investors investing in India had still not increased through the minor economic reforms of 1980's. As per table I although FDI inflows into the country increased throughout the pre-reform period and even the high annual growth rates of $241 \%$ and $451 \%$ were registered in years 1984 and 1985 respectively, but taking a closer look into the figures one could argue that these high annual growth rates of few years in the pre-reform period were quite misleading in the sense that in absolute terms actually one could find that in the entire pre-reform period FDI inflows in any of the year had never touched the marginal mark of even $\$ 0.5$ billion.

In the post reform period as can be seen from the fig. 2 that there is no comparison in terms of FDI inflows into the country in the pre and post reform period as in none of the years of the pre-reform period the annual FDI inflows into the country touched 0.5 billion mark but in the post reform period one could clearly infer from the table IV and fig. 2 that there has been a good performance of Indian economy in terms of attracting FDI inflows into the country. The small 1 billion dollars of FDI inflows was first time registered in 1994 and then onwards there was a continuous increase in the FDI inflows into the country from 2.14 billion in 1995 to 5.12 billion in 2001 .

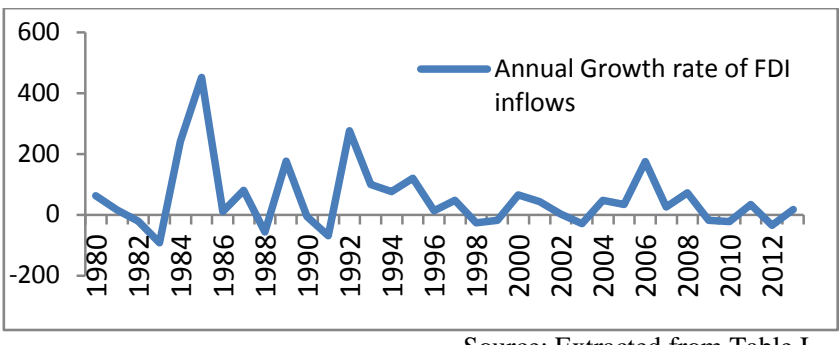

Fig. 2 Annual Growth Rate of FDI inflows

One could easily argue from fig. 2 that the fluctuations in the annual growth rate of FDI inflows into the country were much higher in pre-reform period in comparison to the both of the decades of the post reform period. With the revision of Press Note 18(Misra \& Puri, 2011) which placed various restrictions on foreign investors for setting up businesses in India and government relaxation of foreign ownership in 6 sectors out of 8 which were reserved for public sector, no FDI was allowed in them under the first guidelines of new industrial policy of 1991. It was to be expected that the performance of Indian economy in terms of attracting FDI would be further increased as it can be verified from the table I in the second decade of the post reform period the foreign investor's confidence in Indian economy got further boosted as FDI inflows into the country increased from 5 billion in 2002 to 20 billion in 2006. Further they almost doubled when they reached to a record high of almost 43 billion in 2008. There was a reduction in FDI inflows into the country due to world recession in 2008, but it again gained momentum in 2011.

TABle IV AnNual Average Growth Rate OF Net FDi InFlow

\begin{tabular}{|l|c|c|}
\hline \multicolumn{1}{|c|}{ Periods } & $\begin{array}{c}\text { FDI inflow in } \\
\text { Billion }\end{array}$ & $\begin{array}{c}\text { Growth } \\
\text { Rate }\end{array}$ \\
\hline $\begin{array}{l}\text { Pre Reform period } \\
\text { (1980-1990) }\end{array}$ & 0.11 & 78.39 \\
\hline $\begin{array}{l}\text { Post Reform period Phase I } \\
\text { (1991-2001) }\end{array}$ & 2.13 & 57.10 \\
\hline $\begin{array}{l}\text { Post Reform period Phase II } \\
\text { (2002-2012) }\end{array}$ & 21.24 & 26 \\
\hline $\begin{array}{l}\text { Overall post reform period } \\
\text { (1991-2013) }\end{array}$ & 12.40 & 40.45 \\
\hline Overall period (1980-2013) & 8.43 & 52.73 \\
\hline
\end{tabular}

When we make the comparative analysis in trends of FDI inflows into the country in the pre and post reform period, some figures can mislead and lead to wrong interpretation. It can be found from table IV the annual decadal growth rate of the pre-reform period is almost $79 \%$ which is much higher in comparison to the first decade of the post reform period in which it was $57 \%$ and in the second decade of the post reform period it was estimated to be just 26 percent. The overall growth rate of FDI inflows in the entire post reform period was estimated to be $40 \%$ but when we check the FDI inflows in the absolute value terms, there is no comparison between the pre and post reform period in terms of FDI inflows into the country. FDI inflows into the country had not reached half a billion mark in entire prereform period in any of the year and the annual average of FDI inflows into the country in the pre-reform period was just 0.11 billion in comparison to the first decade of the post reform period in which it was estimated to be around 2.13 billion with the further reforms made in 2000's regarding the FDI policy, the average decadal growth rate of FDI inflows into the country was found to be $21.24 \%$ in the second phase of post reform period and the overall average growth rate of the entire post reform period of FDI inflows was found to be 12.40 percent. So it can be concluded that the economic reforms of 1991 made a significant impact in terms of attracting FDI into the country.

\section{REGRESSION ANALYSIS}

$($ GDPgr $)=\beta 0+\beta 1$ (Impgr) $+\beta 2$ (FDIgr) $+\beta 3$ Dum + et

Where GDPgr is the growth rate of Gross Domestic Product, Impgr is the growth rate of Imports and FDIgr is the growth rate of Foreign Direct Investment Inflows. Dummy variable is a proxy variable used for economic reforms of 1991 . In addition to that $\beta 0$ is a constant term and $\beta 1$ is the coefficient of the respective explanatory variable (Impgr) that explains how much the (Impgr) affects the GDP growth rate (GDPgr). Similarly $\beta 2$ is the coefficient of Foreign Direct Investment growth rate i.e. (FDIgr) which explains how much FDI inflows impacts the dependent variable and $\beta 3$ is the coefficient of Dummy variable. 
TABLE V REGRESSION RESULTS OF OVERALL TIME PERIOD

\begin{tabular}{|l|c|c|c|c|}
\hline Variable & Coefficient & Std. Error & t- Statistic & Prob \\
\hline Impgr & 0.058231 & 0.033339 & 1.746637 & 0.0909 \\
\hline FDIgr & -0.001742 & 0.003392 & 0.513669 & 0.6112 \\
\hline Dum & 1.302027 & 0.735778 & 1.769593 & 0.0870 \\
\hline
\end{tabular}

Note figures are taken in average annual rates

It can be found from Table $\mathrm{V}$ that GDP growth rate (GDPgr) is not affected FDIgr throughout the pre and post reform period. In the entire pre reform period FDI inflows never touched half a billion mark as can verified from the table I so one can argue that this marginal increase in FDI inflows would certainly have made no significant impact on the GDP growth rate. In the post reform period although various liberal measures were introduced as far as FDI policy is concerned but again one can argue that the most important problem associated with FDI inflows is that a major chunk of FDI inflow was not going into the new capital formation thereby increasing the overall production and productivity of the entire economy. During that time more than 40 percent of the FDI inflows were used to purchase shares in the existing enterprises for obtaining ownership rights. In fact large MNC's were very clever in using these liberal measures as far as FDI policy in the post reform period was concerned by purchasing majority stakes in the existing industrial enterprises. Thus one can say that this trend of FDI inflows in the post reform period has just led to change in ownership rights without due consideration to industrial production, productivity and competition. Imports on the other hand are found to have made significant impact on GDPgr, this finding seems to be highly realistic as far as Indian economy is concerned our imports mainly consists of raw materials, capital equipments, intermediate goods, technology etc. which add to the production and productivity thereby increasing GDP growth rate in the long run. It is well known fact that imports augment exports as well. Thus, to put a country like India on the higher GDP growth proper policies should be framed which will give due consideration to both exports and imports. Finally, it can be verified from table $\mathrm{V}$ that the coefficient of Dummy variable (Dum) i.e. $\beta 3$ is found to be significant and positive as well, so one can conclude that economic reforms of 1991 made a significant impact on GDP growth rate. It can argued that India did witness high GDP growth rate in many years of pre reform period as well but that growth was unsustainable and finally got culminated into the BOP crisis of 1991. India in the post reform period (in 1990's in particular) was considered one of the fastest growing economies of the world.

\section{CONCLUSION}

From the findings one can easily conclude that Indian economy performed really well in the post reform period. It was found that the major determinants of GDP i.e. imports and FDI inflows both increased substantially in post reform era in contrast to the pre reform era. The dummy variable made it clear that the liberal measures of 1991 led to sustainable increase in GDP growth rate in contrast to the unsustainable growth of 1980's. It was further found that FDI inflows were insignificant in explaining GDP growth rate although they increased drastically in the post reform period. It is recommended to the policy makers that FDI policies should not be just based on liberal measures but FDI Inflows should be directed towards new capital formation thereby increasing the overall production and productivity of the entire economy. Major chunk of FDI inflows into India were used to purchase shares in the existing enterprises for obtaining ownership rights. In fact large MNC's were very clever in using these liberal measures as far as FDI policy in the post reform period was concerned by purchasing majority stakes in the existing industrial enterprises. Thus one can say that the trend of FDI inflows in the post reform period has just led to change in ownership rights without due consideration to industrial productivity and competition. Imports were found to be significant in explaining GDP growth rate, so it is further recommended to continue the imports of essential raw materials, capital equipments, technical expertise etc. without any stumbling blocks.

\section{REFERENCES}

[1] Ahluwalia, S.M. (2002). Economic Reforms in India Since 1991: Has Gradualism Worked? Journal of Economic Perspectives, 16(3),67-88.

[2] Akhtar, G. (2013). Inflows of FDI in India: Pre and Post Reform Period. International Journal of Humanities and Social science Invention, 2(2), 01-11.

[3] Bhagwati, J. \& Srinivasan, N.T.(2002). Trade and Poverty in the Poor Countries. American Economic Review, 92(2), 180-183.

[4] Borenszteina, E., Gregori De. J., et al. (1998). How does foreign direct investment affect economic growth? Journal of International Economics, 45(1), 115-135.

[5] Din, ud Muslih. (2004). Exports, Imports and Economic Growth in South Asia: Evidence using Multivariate Time - Series Framework. The Pakistan Development Review, 43(2), 105-124. Retrieved from http://www.jstor.org/stable/41260615.

[6] Misra, K. S. \& Puri, K.V. (2011). Indian Economy- Its Development Experience. Himalayan Publishing House Pvt. Ltd.

[7] Nayyar, D. (1987). India’s Export Performance 1970-85: Underlying Factors and Constraints. Economic and Political Weekly, 22 (19/21). Retrieved from http://www .jstor .org/stable/4377012.

[8] Nunnenkamp, P. \& Chakraborty, C.(2008). Economic reforms, FDI, and Growth in India: A sector level Analysis. World Development, 36(7), 1192-1212. Elseveir Ltd

[9] Panagariya, A. (2004). Growth and Reforms during 1980s and 1990s. Economic and Political Weekly, 39(25), 2581 -2594. Retrieved from http://www.jstor.org /stable/4415173.

[10] Quibria, G. M. (2002). Growth and Poverty. Lessons from East Asian Miracle Revisited. Asian Development Bank Research Institute, research paper series paper no. 33.

[11] Rai, K. S. \& Jhala, P. (2015). Impact of Exports and Imports on Growth Rate of India: An Empirical Enquiry. Pacific Business Review International, 8(6), 53-58.

[12] Rodrik, D. (2002). In Search of the Deep Determinants of Economic Growth, Institutions, Integration and Geography. Retrieved from http:// projects. iq.harvard .edu /files /wcfia /files/530_rodrik6.pdf.

[13] Sen, A. \& Dreze, J. (1995). Economic Development and Social Opportunity. Calerendon Press, Oxford.

[14] Sarkar, P. \& Bhattacharyya, B. (2005). Trade Liberalization and Growth: Case Studies of India and Korea. Economic and Political Weekly, 40(53), 5635-5641. Retrieved from http://www.jstor.org/ stable $/ 4417618$.

[15] Virmani, A. (2001). India's 1990-91 Crisis: Reforms Myths and Paradoxes. Planning Commission of India Working paper no.4/2001PC. 